Slobodan Cvetanović ${ }^{1}$

Vojislav llić ${ }^{2}$

Danijela Despotović ${ }^{3}$

Vladimir Nedić ${ }^{4}$
JEL: 031, 034

DOI: 10.5937/industrija43-7908

UDC: $330.341 .1(497-15)$

005.35:338.486.2

Original Scientific Paper

\title{
Knowledge Economy Readiness, Innovativeness and Competitiveness of the Western Balkan Countries
}

\author{
Article history: \\ Received: 13 March 2015 \\ Sent for revision: 7 April 2015 \\ Received in revised form: 20 July 2015 \\ Accepted: 22 July 2015 \\ Available online: 15 October 2015
}

\begin{abstract}
The Western Balkan countries have set themselves the goal to join the European Union as soon as possible. Accordingly, they must adjust the key components of their development policies to the Europe 2020 strategy, focusing on key priorities such as smart, sustainable and inclusive growth. This paper explores the relationship among knowledge economy readiness, innovativeness, and competitiveness of six Western Balkan countries (Albania, Bosnia and Herzegovina, Macedonia, Serbia, Croatia, and Montenegro) and the group of six selected neighboring EU countries (Austria, Bulgaria, Greece, Hungary, Romania, and Slovenia). The paper relies on the data obtained from the Knowledge Economy Index of the World Bank Institute, INSEAD's Global Innovation Index and the Global Competitiveness Index of the World Economic Forum for 2013. Obtained data from all three sources indicated significantly lower readiness for the development of economy based on knowledge, innovation and competitiveness in the Western Balkans countries in comparison to the selected EU countries. The analysis of the interdependence of the aforementioned variables points to: a) statistically significant correlation between the indicator knowledge economy index and the global innovation index for both groups of countries; b) statistically significant linear correlation between innovativeness and innovation efficiency ratio for the Western Balkan countries. Conversely, no
\end{abstract}

\footnotetext{
${ }^{1}$ University of Niš, Faculty of Economics, Serbia

2 University of Belgrade, Teacher's Training Faculty, Serbia

3 University of Kragujevac, Faculty of Economics, Serbia, ddespotovic@kg.ac.rs

${ }^{4}$ University of Kragujevac, Faculty of Philology and Arts, Serbia
} 
Cvetanović S. et al.: Knowledge Economy Readiness, Innovativeness and...

respective correlation has been registered for the group of selected EU countries; c) no statistically significant correlation between the global innovation index and the global competitiveness index in the Western Balkan countries, while in respect of the group of selected EU countries, the existence of significant linear correlation between these variables has been revealed.

Keywords: knowledge economy, innovativeness of the economy, country's competitiveness, Western Balkans, European Union.

\section{Spremnost za razvoj ekonomije bazirane na znanju, inovativnost i konkurentnost zemalja Zapadnog Balkana}

Apstrakt: Zemlje Zapadnog Balkana postavile su za cilj pridruživanje Evropskoj uniji u što je moguće kraćem roku. U tom smislu, ove zemlje moraju prilagoditi svoje politike razvoja strategiji Evropa 2020, u čijem se centru nalazi izgradnja društva znanja, rast inovativnosti $i$ unapređenje konkurentnosti. U radu je na osnovu podataka uzetih iz tri kompozitna indeksa (Knowledge Economy Index Instituta Svetske banke, Global Innovation Index INSEAD-a i Global Competitiveness Index Svetskog ekonomskog foruma) za 2013. godinu istraživana povezanost spremnosti za razvoj ekonomije bazirane na znanju, inovativnosti $i$ konkurentnosti šest zemalja Zapadnog Balkana (Albanija, Bosna i Hercegovina, Makedonija, Hrvatska, Srbija i Crna Gora) $i$ isto tolikog broja selektovanih država Evropske unije iz njihovog najbližeg okruženja (Austrija, Bugarska, Grčka, Mađarska, Rumunija, Slovenija). Po podacima iz sva tri izvora, konstatovano je izraženo zaostajanje spremnosti za razvoj ekonomije bazirane na znanju, inovativnosti i konurentnosti zemalja Zapadnog Balkana za selektovanim zemljama EU. Analizom međuzavisnosti pomenutih varijabli ustanovljena je: a) statistički značajna korelacija između indikatora spremnosti za razvoj ekonomije znanja i globalnog indeksa inovativnosti za obe grupe zemalja; b) statistički značajna korelacija između globalnog indeksa inovativnosti i indeksa inovacione efikasnosti za zemlje Zapadnog Balkana, za razliku od grupe selektovanih zemalja EU; c) nije detektovana statistički značajna korelacija između globalnog indeksa inovativnosti i globalnog indeksa konkurentnosti za zemlje Zapadnog Balkana, dok je za grupaciju selektovanih zemalja EU ustanovljeno postojanje značajne linearne korelacije ovih varijabli.

Ključne reči: Ekonomija znanja, inovativnost privrede, konkurentnost zemlje, Zapadni Balkan, Evropska Unija. 
Cvetanović S. et al.: Knowledge Economy Readiness, Innovativeness and...

\section{Introduction}

In the past thirty years, plenty of economic research has confirmed that the complex of knowledge is a key determinant of productivity growth. Investment in knowledge increases the effect of other production factors, thus enabling their rapid and efficient transformation into new products and processes. Since this form of investment is not subject to the law of diminishing returns, it is clear that investment in the creation of new knowledge is crucial for longterm economic growth (see, for example, Zubović, 2010). As a reminder, according to the neoclassical production function, adding new units of capital into the production results in low returns, which can be compensated by new technological processes (Barro \& Sala-i-Martin, 2003). In new or endogenous theories of economic growth, knowledge increases return on investments, which, in turn, contributes to the accumulation of knowledge and accelerated generation of economic growth (Romer, 1990). This results from more efficient methods of production organization, the creation of new products and improvement of existing products and processes. This opens the possibility of an effective increase of investment, which leads to long-term sustainable economic growth. Knowledge is also transferred from one industry to another, which allows for a multiple use of a new idea, with almost negligible additional costs.

Economic development has always been based on knowledge. However, the scope and importance of knowledge for the economic processes have fundamentally changed in recent years, when productivity growth, driven by technological and organizational innovation, has become a key source of economic growth (Huggins \& Izushi, 2007).

Analysis of the importance of innovativeness of the economy for the economic growth has been a common theme of macroeconomic research. Starting with Solow (1956), who published the results of his research in mid-1950s, it has continued until the present day. The emergence of a new (endogenous) growth theory in the late nineteen-eighties and early nineteen-nineties particularly contributed to the articulation of such views in economic science.

Porter noted that innovation is the most important source of a country's competitiveness (1990). Innovations are predominantly based on the results of fundamental and applied research in the developed world, which is, in theoretical terms, directly related to the affirmation of the concept of national innovation system. The very emergence of this concept is related to Freeman (1987), while its theoretical shaping is found in the works of Lundvall (1992) and Nelson (1993). Since the purpose of the national innovation system lies in the creation, generation, and diffusion of technology, its main characteristics are reflected in the ability of participants to use these activities in order to apply technologies that lead to the creation of the greatest economic values. 
Cvetanović S. et al.: Knowledge Economy Readiness, Innovativeness and...

Competitiveness of a country is the field of economic theory, focusing on the analysis of the facts and policies that shape the country's ability to create and maintain an environment that creates more value for the companies and prosperity for its people (Gareli, 2012). Some researchers believe that competitiveness has a status of "natural law of modern capitalist economy" (Kitson et al., 2004). Therefore, the measurement of a country's competitiveness and the creation of a meaningful policy of competitiveness has officially become an institutional activity in many countries during the last decade of the previous century. The United States of America were the pioneers in promoting and institutionalizing the imperative of improvement of a country's competitiveness. Specifically, in the early 1990s, the USA established the State Council on Competitiveness, aimed at improving the competitiveness of the American economy. Almost simultaneously, the EU Commission established the European Competitiveness Council, thus becoming obliged to publish an annual Report on the competitiveness of the EU countries' economy. In addition to the process of institutionalization of the countries' competitiveness of, a number of very respectable organizations appeared, dealing with quantification of competitiveness. The ones worth mentioning are the World Economic Forum (Geneva, Switzerland), The Competitiveness Institute (Barcelona, Spain), the Council on Competitiveness (Washington, USA), and the Institute for Strategy and Competitiveness (Harvard, USA).

Starting from the above stated observations regarding the countries knowledge economy readiness, innovativeness and competitiveness, the aim of this study is to detect differences in the achieved values and the mechanisms of interaction among the three very important economic phenomena, following the example of the Western Balkan countries (Albania, Bosnia and Herzegovina, Macedonia, Serbia, Croatia, and Montenegro), and a group of neighboring EU countries (Austria, Bulgaria, Greece, Hungary, Romania, and Slovenia). The selected Western Balkans group included Croatia, as the relatively most innovative and most competitive country in this group, which became the member of the EU on 1 July 2013. Furthermore, the selected EU countries, with the exception of Austria and, to a certain extent, Slovenia, belong to the very bottom of the list of EU countries, judging by the criteria of innovativeness and competitiveness (Nedić et al., 2013; Cvetanović et al., 2013; Despotović, et al, 2014). This fact should be taken into account when making judgments about the perceived differences in relation to: knowledge economy readiness, increasing innovativeness, and improving competitiveness of the Western Balkans countries and the group of selected EU countries in their neighborhood (Cvetanović \& Nedić, 2013).

One of the questions that arises here concerns the relative position of the Western Balkan countries concerning knowledge economy readiness, innovativeness of the economy and competitiveness in relation to the group of 
Cvetanović S. et al.: Knowledge Economy Readiness, Innovativeness and...

selected EU countries. Another question concerns the differences in interdependence among the mentioned economic phenomena in relation to these two groups of countries.

The answer to these questions largely affects the character of the message of this research, which is to be sent to makers of innovation policies and policies aimed at improving the competitiveness of the Western Balkan countries. This we believe to be the strategically important aspect of managing the development of the Western Balkan countries, since they set the goal to join the European Union as soon as possible. In this regard, the Western Balkan countries must adapt their development policies to the strategy Europe 2020, whose primary goal is the construction of a knowledge society, the growth of innovativeness and improving competitiveness.

In defining the above mentioned issues, the authors are aware of the relevance of the discussion on the adequacy and quality of general scores, given the basis of the composite indicators, Knowledge Economy Index (KEI), Global Innovation Index (GII), and the Global Competitiveness Index (GCI). Therefore, doubt in their validity comes to the forefront. This is especially important for the countries in late transition, including all Western Balkan countries, except Croatia, since, for them, the mentioned indices are aggregated from an incomplete set of metrically defined indicators. However, we believe that, despite the possible critical views, purposefulness of the use of composite indices for the expression of complex economic phenomena is justified, especially in the comparative analysis of individual groups of countries, as is the case in this paper.

The structure of the paper has been adapted to the defined purpose of the research. Specifically, after the introductory notes, a brief overview of previous research is given, placing emphasis on the main problems and unresolved dilemmas concerning the definition of the three observed phenomena (knowledge economy readiness of countries, innovativeness of the economy, and a country's competitiveness). After that, the metrics of the used methodological framework for quantifying these macrophenomena is presented. The third section presents a comparative analysis of the knowledge economy readiness, innovativeness and competitiveness of the Western Balkan countries in relation to the selected EU countries. In the last, fourth part of the article, the interdependence of the aggregate values of KEI, GII, and $\mathrm{GCl}$ are analyzed for the two groups of countries. Finally, the concluding remarks are given. 
Cvetanović S. et al.: Knowledge Economy Readiness, Innovativeness and...

\section{Review of literature}

Over the past decades, the categories such as knowledge economy, innovativeness of the economy, and competitiveness of a country have often been analyzed in plenty of economic research (Acs, de Groot \& Nijkamp, 2013; Delgado, Ketels, Porter \& Stern, 2012; Atkinson \& Ezell, 2012). However, despite a large number of papers published on this topic, it can be concluded that theory has reached no consensus on how to precisely define these phenomena. What is particularly intriguing is their interdependence and interaction, which are also the subject of a significant number of scientific papers.

The syntagm "knowledge society" was first used by Peter Drucker in 1969 (1969), who describes the knowledge society as a society of mobility, which is the most competitive society in the history of mankind (Drucker \& Drucker, 1993). Knowledge society is based on the ability of economic actors to create new knowledge and to transform it into economic value and wealth with the help of innovations (Huggins \& Izushi, 2002). In this society, knowledge and innovations become the most important sources of competitive advantage (Machlup, 2014). Therefore, the issues of measuring and understanding innovativeness of countries in this environment are of vital importance.

Analysis of the impact of different categories of knowledge on innovative performance can be found in the work of Frenz \& Letto-Gillies (2009). In this paper, the authors view the complex of knowledge in four forms: a) internal inhouse knowledge b) transferred knowledge, created through the purchase of resources to encourage innovativeness $\mathrm{c}$ ) knowledge generated through the collaboration of companies with external R\&D entities and d) external knowledge gained within the larger organization (for example, multinational companies). Results reached by the application of regression analysis suggest a significant positive impact which categories $a, b$, and $d$ have on innovative performance. On the other hand, the knowledge gained through collaboration with external R\&D entities (category c) shows a much less noticeable effect on the innovative performance of organizations. The authors are of the opinion that this result can be explained by the fact that the exchange of knowledge within the company takes place in the environment characterized by unique and homogeneous organizational culture of the company, which increases the ultimate impact of knowledge exchange on innovative performance.

Possibilities for researchers, as the direct creators of new knowledge, to commercially valorize their findings through innovation systems are explored in the works of Cooke $(2001,2004)$. The author points to the fact that the quality of the national innovation system plays a key role in the transfer of 
Cvetanović S. et al.: Knowledge Economy Readiness, Innovativeness and...

knowledge in the process of improving the competitiveness of a country, so that it must be adequately supported by specific macroeconomic measures.

In today's economic conditions, a country's competitiveness has become a central subject of development policies in economically leading and developing countries alike (Önsel et. al., 2008). The opinion that the proper management of the competitiveness of a country is an important prerequisite of the improvement of welfare and living standard of the population prevails (Ulengina, 2011). Competitive countries are areas in which companies want to invest and produce (Kitson et. al., 2004). Considering the ways out of the latest economic crisis, Porter and Rivkin suggest that the key lies in increasing innovativeness and improving the competitiveness of the economy on that basis (2012).

Ståhle and Ståhle (2006) see the problem in basing the knowledge economy on intangible factors, focusing attention on their understanding and measurement. As a starting methodological perspective, the authors use the categories national intellectual capital and a country's competitiveness. According to them, no single methodological framework can monitor the dynamics of economic stimuli and anticipate their performance. However, by combining elements from both frameworks (which usually partly overlap), the authors try to employ the synergistic effect and reveal the nature and degree of interaction among intellectual capital, competitiveness, and dynamics of economic growth in some countries. Their conclusions positively evaluate the use of sectoral trend analysis in elucidating the interdependence of a country's intellectual capital, as a component of a country's innovativeness of the economy, and the factor of competitiveness of a country on the international market.

Expanding the methodological frameworks of investigating a country's competitiveness arises by incorporating requirements of sustainable development as a new paradigm of development Coenen \& Díaz López (2010). The goal of innovativeness is not closely related to the improvement of competitiveness and acceleration of economic growth, but is determined by the achievement of sustainable win-win relationship between competitiveness, on the one hand, and environmental sustainability and social planning, on the other hand (Cvetanović, et.al, 2014). Seen in this light, interdependence between innovativeness of the economy and competitiveness of a country implies the necessity of modernization and adaptation of existing methodological frameworks of quantification of innovativeness and competitiveness in line with the requirements of the paradigm of sustainable development.

Despite a current debate on the phenomena of the knowledge economy innovativeness of the economy and competitiveness of a country, the subjective opinion of the author of this work is that more exact studies on their 
Cvetanović S. et al.: Knowledge Economy Readiness, Innovativeness and...

interdependence and interaction are usually confined to the level of companies and clusters, while at the national level, they are still unsatisfactory. This can be explained by the high level of abstraction of the methodological frameworks applied at the level of the national economy, which are, despite the efforts to design appropriate metrics, still far from unambiguous quantification of these macroeconomic phenomena, in particular the phenomenon of national competitiveness, as seen by the results of individual analyses (Lall, 2001; Staskeviciut and Tamošiūnienè, 2010). On the other hand, the paradigm of sustainable development imposes the need for a global overview of these phenomena and change of methodological frameworks for describing them, primarily at the national and wider regional level.

\section{Methodology of reference frameworks of $\mathrm{KEI}$, GI, and GCI}

Attempts to define the methodological framework and metrics of the knowledge economy, innovativeness of the economy and competitiveness of a country at the wider national level have attracted the attention of a number of researchers and practitioners. In the course of doing research, the authors of this paper detected the following as the most convenient and the most comprehensive methodological frameworks of the phenomenon of countries' knowledge economy readiness, innovativeness of the economy, and a country's competitiveness:

- KEl (Knowledge Economy Index) of the World Bank, describing the achieved level of the knowledge economy (2013),

- GII (Global Innovation Index) of the Cornell University, INSEAD, and World Intellectual Property Organization, describing the achieved level of innovativeness (Dutta, 2012), and

- $\mathrm{GCl}$ (Global Competitiveness Index) of the World Economic Forum (WEF), describing the achieved level of competitiveness (2012).

\subsection{KEI}

To facilitate the countries' construction of the knowledge society, the World Bank developed the Knowledge Assessment Methodology (KAM), which identifies the sectors or specific areas to which policy makers should pay particular attention. The approach is based on the quantification of two indices: Knowledge Economy Index (KEI) and Knowledge Index (KI) (see Fig. 1). 
Cvetanović S. et al.: Knowledge Economy Readiness, Innovativeness and...

Figure 1. The structure of the KEI

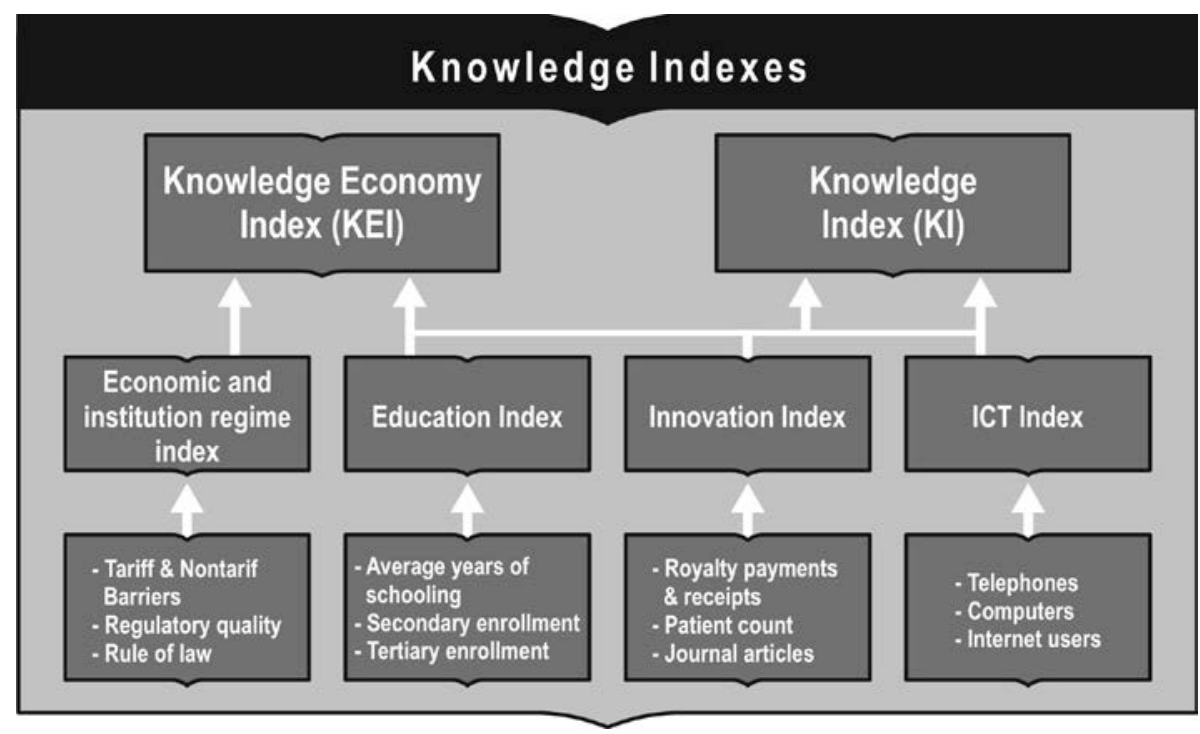

Modified according to: http://siteresources.worldbank.org/INTUNIKAM/Resources/2012.pdf, p.1

$\mathrm{KEI}$ is an indicator that measures the ability of a country or a region to develop the knowledge economy, i.e. suitability of an environment for the efficient use of knowledge for economic development. It is an aggregate index that represents the overall level of development of a country or region in relation to the knowledge economy. It is calculated on the basis of the average normalized performance of a country or a region for all 4 pillars related to the knowledge economy: economy and institutions, education and human resources, the innovation system, and information and communication technology (Chen \& Dahlman, 2005, p. 4).

\subsection{GII}

Innovativeness is the result of numerous interactions among the economy, the state, and the academia in the development of science and technology. The result of these interactions is the formation of a national innovation system. Interactions within the system influence innovativeness and performance of companies and the economy as a whole. The system's "ability and power to distribute knowledge", i.e. the ability to provide innovators with timely access to relevant sources of knowledge is vital. Confederation of Indian Industry, together with INSEAD (The Business School for the World), and Canon India, created the Global Innovation Index (GII), whose main objective is the quantification of the achieved level of innovativeness of some countries. The 
Cvetanović S. et al.: Knowledge Economy Readiness, Innovativeness and...

aim of this report is also the recognition of the obstacles that stand in the way of effects based on the use of innovation in companies and the economy as a whole. GII is divided into the Innovation Input Index (III) and the Innovation Output Index (IOI).

III represents the pillars that, in the broadest context, determine the national capacity for innovation. In the broadest sense, it focuses on the capacity of the environment for the creation, diffusion, and application of innovation in the economy. IOI is the result of the transformation of inputs into outputs. This work places special emphasis on the indicator Innovation Efficiency Ratio (IER), which represents the ratio between the III and the IOI. This is because it can be assumed that it focuses on the quality of the national innovation system of individual countries (Fig. 2).

Figure 2. The structure of the GII

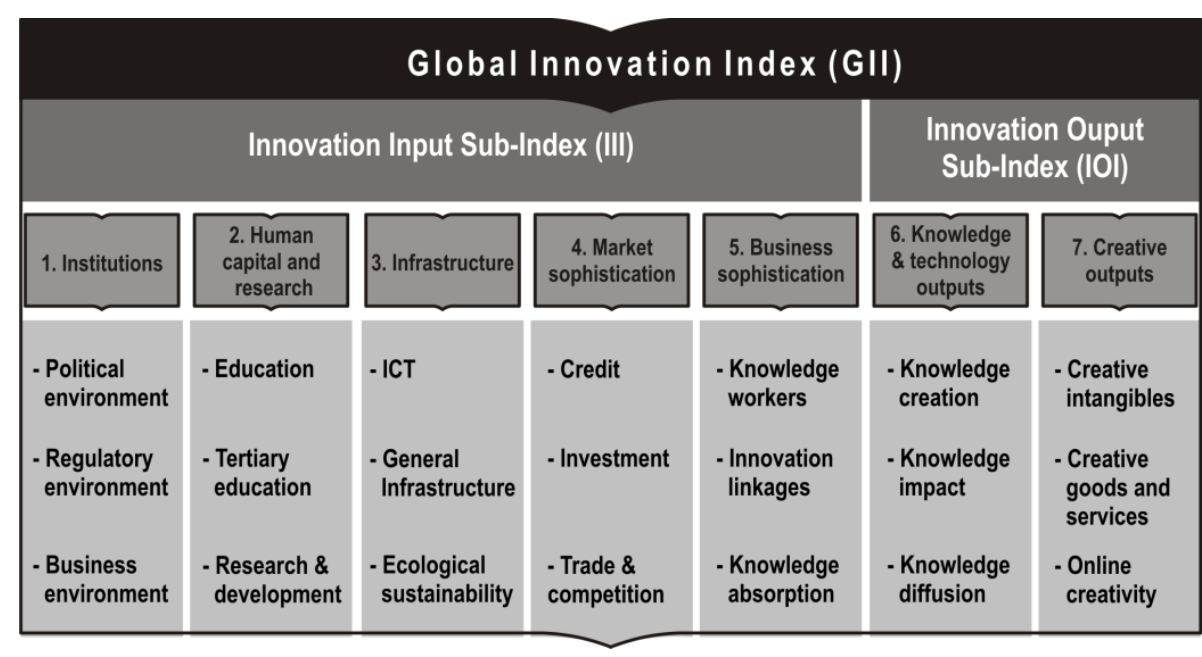

Modified according to: Dutta \& Lanvin, 2013, p.40

\section{$3.3 \mathrm{GCl}$}

Economic theory uses different ways to explain the competitiveness of countries on the global market. In the broadest sense, the competitiveness of the national economy is based on the measurement of key macroeconomic indicators and the achieved level of living standard, with special focus on productivity. In the narrow sense, this concept is defined as a country's ability to export its products to the world market. There is no generally accepted methodology for the quantification of macroeconomic competitiveness. In practice, there are several approaches to its measurement, among which the Global Competitiveness Index $(\mathrm{GCl})$ of the World Economic Forum stands out 
Cvetanović S. et al.: Knowledge Economy Readiness, Innovativeness and...

for its importance. It is a comprehensive index, which measures the micro and macroeconomic foundations of national competitiveness. The metrics operates on the basis of more than 150 variables, grouped into twelve pillars of competitiveness.

Figure 3. The structure of the $\mathrm{GCl}$

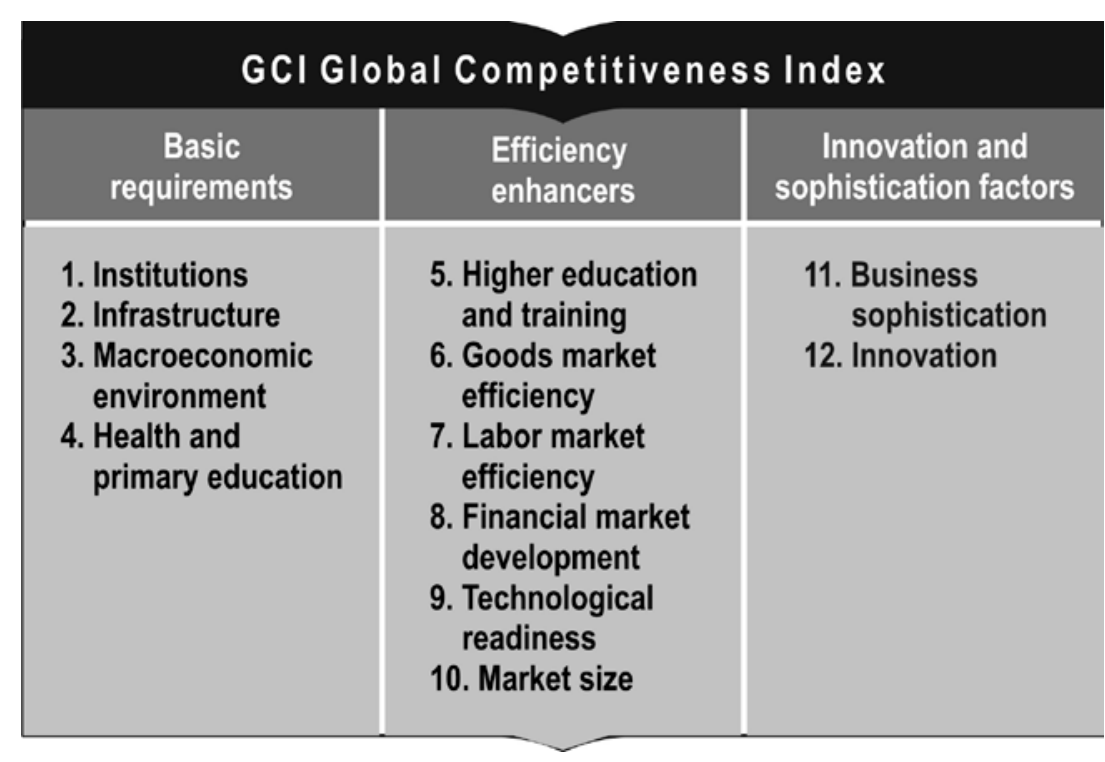

Modified according to: WEF, 2012, p.8.

It is clear that none of the sources provides perfect information, as well as that the results vary from study to study due to different set of indicators, weight factors, methods of analysis, and others. However, it can be noted that the indices presented in these studies show a significant degree of convergence, so that it is possible to reach acceptable conclusions.

In order to analyze the general level of readiness of the studied groups of countries for the knowledge economy, this paper relies on the KEI database, focusing on the values of the four structural pillars that make up the index. The GII Report has provided the data on the values of III, IOI, and IER. The third report has provided the data on the $\mathrm{GCl}$ of the analyzed economies in 2012.

The applied research in this paper has been carried out in three stages, using the appropriate methodology, as follows:

- The analysis of the respective reference frameworks for the identification of key indicators of the knowledge economy, innovativeness, and 
Cvetanović S. et al.: Knowledge Economy Readiness, Innovativeness and...

competitiveness of the economies, and taking, filtering, and structuring the available data (http://info.worldbank.org/etools/kam2/KAM_page1.asp; http://www.globalinnovationindex.org/;

http://www.weforum.org/issues/global-competitiveness),

- The comparative analysis of the knowledge economy readiness, innovativeness and competitiveness of the Western Balkan countries, with the aim of identifying the gap between them and the group of the selected EU countries, and

- The application of statistical tools (simple linear correlation and regression analysis) to explore the interdependence of $\mathrm{KEI}, \mathrm{GI}$, and $\mathrm{GCl}$ according to the assumed hypothetical model.

\section{Comparative analysis of KEI, GII, and GCl of the Western Balkan countries in relation to the selected EU countries}

The Western Balkan countries, as well as the selected EU countries, are seen as unique regions, which allows for a simple comparison of the indicators of their: a) knowledge economy readiness, b) achieved level of innovativeness and $\mathrm{c}$ ) the level of competitiveness. The observed characteristics of the selected groups of countries are shown aggregately, as the average of the results that the observed countries achieved in the field of the knowledge economy, innovativeness, and competitiveness.

\subsection{KEI}

Fig. 4 gives an overview of the $\mathrm{KEI}$ values and its pillars for the Western Balkan countries and the six selected EU countries. Based on the given graphical representation, the big gap between the countries of the Western Balkans and the selected EU countries in relation to the KEI values can be noted.

It is evident that there is a large gap between the Western Balkan countries and the selected group of EU countries in terms of the value of KEI and its pillars. This gap is especially noticeable in respect of the pillar Economic Incentive Regime, which is a fundamental prerequisite for the development of the knowledge economy, and also in respect of the pillar Innovativeness. On the other hand, the gap between the Western Balkan countries and the selected EU countries is the least in terms of the value of the pillar ICT.

Detailed and in-depth research of the readiness of the selected European countries for the knowledge economy points to the fact that within the pillar Innovativeness, the most problematic variable is the one that reflects the number of patents, while in the field of Economic Incentive Regime, the 
Cvetanović S. et al.: Knowledge Economy Readiness, Innovativeness and...

biggest gap is seen in the case of the variable Tariff \& Nontariff Barriers. Furthermore, the detected trend of improvement of the values of all pillars of KEI for the Western Balkan countries is encouraging (except for the pillar Education, whose trend is for most of the surveyed countries negative). This positive trend is especially pronounced in the case of the pillars with the largest gap in relation to a group of EU countries - Economic Incentive Regime and Innovativeness.

Figure 4. Comparison of the pillars of KEI for the observed groups of countries (most recent available data)

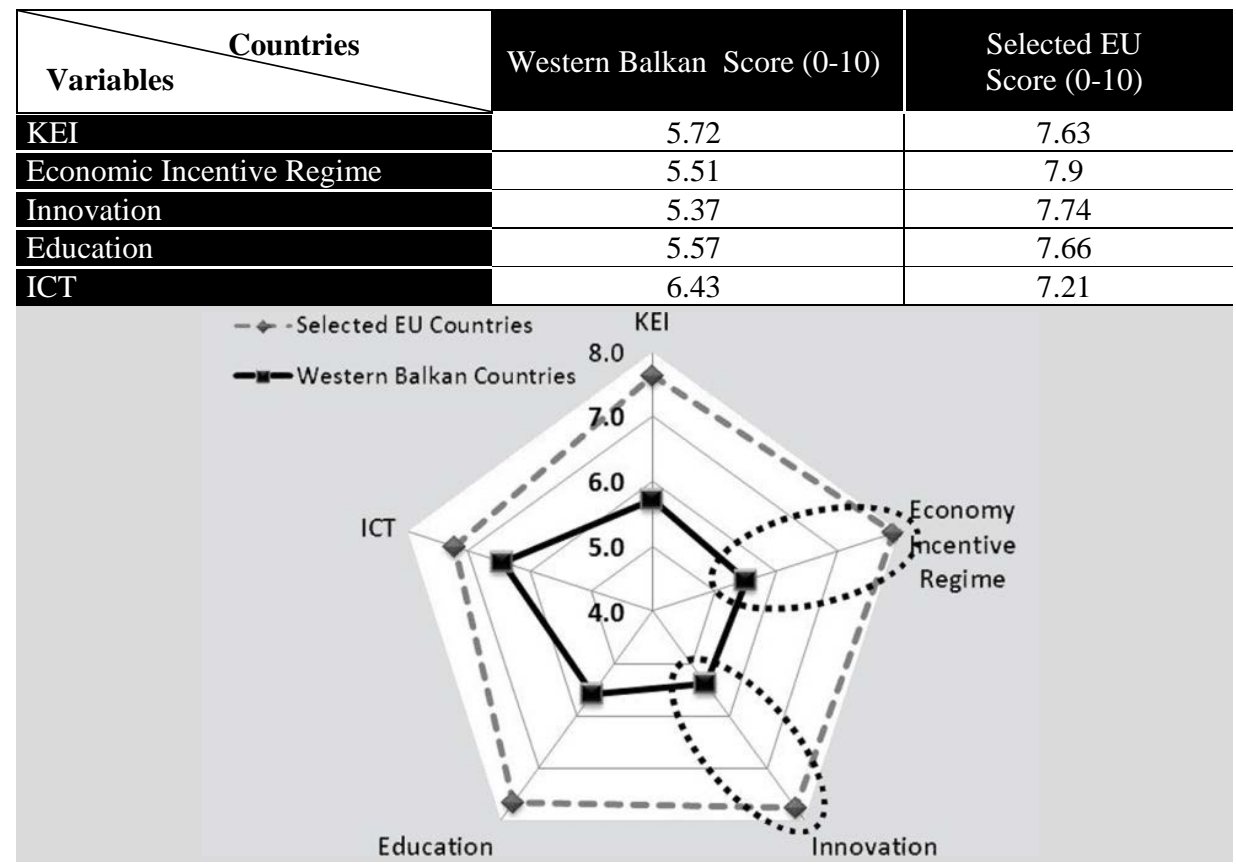

Calculated according to: http://info.worldbank.org/etools/kam2.

\section{$4.2 \mathrm{GI}$}

Fig. 5 shows the values of GII, IER, III and IOI for the Western Balkan countries and the selected EU countries. 
Cvetanović S. et al.: Knowledge Economy Readiness, Innovativeness and...

Figure 5. GII, III, IOI and IER for the Western Balkan countries and the selected EU countries

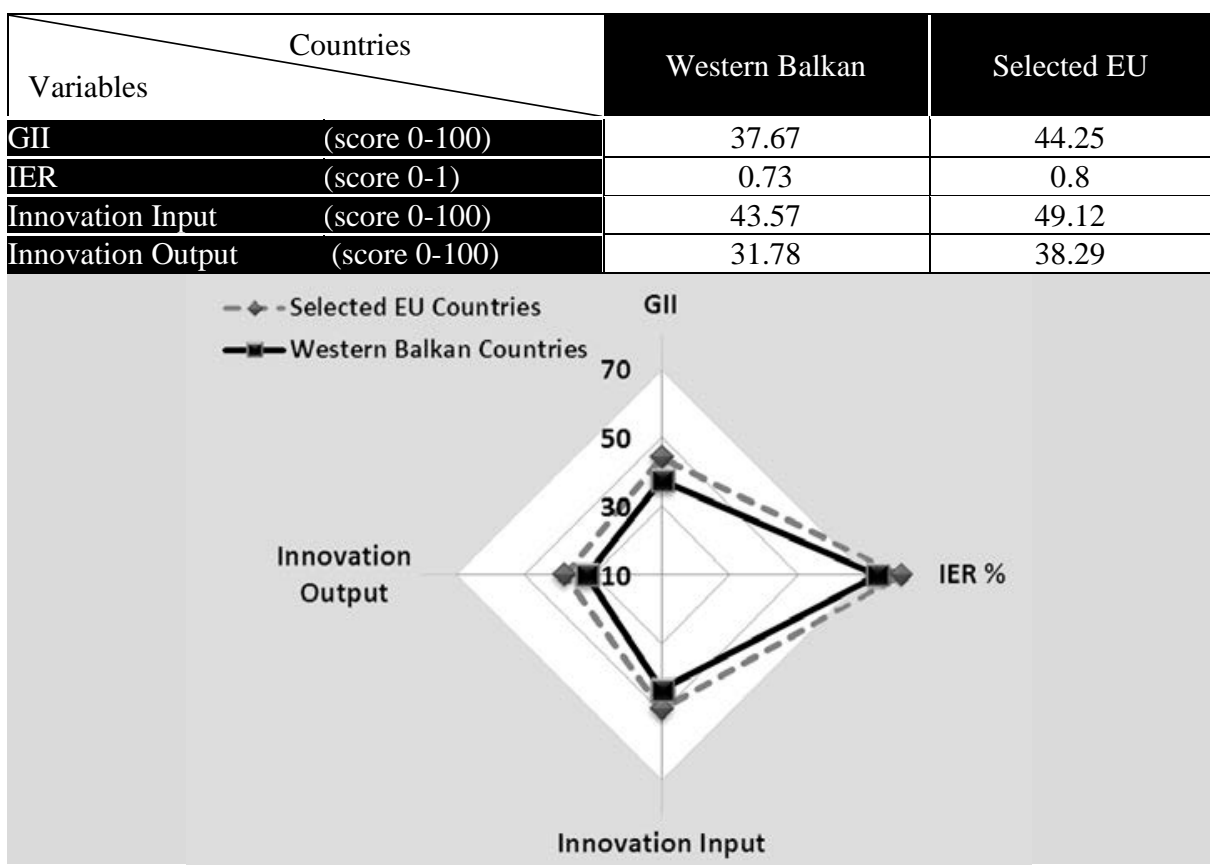

Calculated according to: Dutta \& Lanvin, 2013.

The spider diagram shows that the EU neighbors have a significant, but not insurmountable lead (in respect of the observed parameters, it ranges from $9 \%$ to $17 \%$ ) compared to the countries of the Western Balkans. The least pronounced difference in respect of IER encourages too, which means that with the adequate innovation policy, the Western Balkan countries could reach respectable innovation outputs.

Some studies provide more detailed information (Despotović et. al, 2014; Cvetanović \& Nedić, 2013), indicating that the most critical elements of innovativeness of the Western Balkan countries are institutions and infrastructure, as the input for innovativeness. Knowing that the category of institutions includes assessing the political stability and the rule of law, then these differences are expected. Political instability with many open internal questions is the characteristics of this region, as well as the underdevelopment of basic institutions and the inefficiency of the legal system, particularly in the area of intellectual property protection. The infrastructure gap is also expected due to the slow, incomplete and inefficient transition of countries of the region towards a market economy model. 
Cvetanović S. et al.: Knowledge Economy Readiness, Innovativeness and...

\section{$4.3 \mathrm{GCl}$}

Fig. 6 provides an overview of the values of the Global Competitiveness Index and its three sub-indices 1 ) basic factors of competitiveness; 2) factors to increase efficiency, and 3) factors of innovativeness and sophistication.

Figure 6. The value of the $\mathrm{GCl}$ and its sub-indices

\begin{tabular}{l|c|c}
\hline \multicolumn{1}{|c|}{ Variables } & $\begin{array}{c}\text { Western Balkan } \\
\text { Score (1-7) }\end{array}$ & $\begin{array}{c}\text { Selected EU } \\
\text { Score (1-7) }\end{array}$ \\
\hline GCI & 3.99 & 4.34 \\
\hline Basic requirements & 4.40 & 4.74 \\
\hline Efficiency enhancers & 3.87 & 4.32 \\
\hline $\begin{array}{l}\text { Innovation and sophistication } \\
\text { factors }\end{array}$ & 3.24 & 3.81 \\
\hline
\end{tabular}

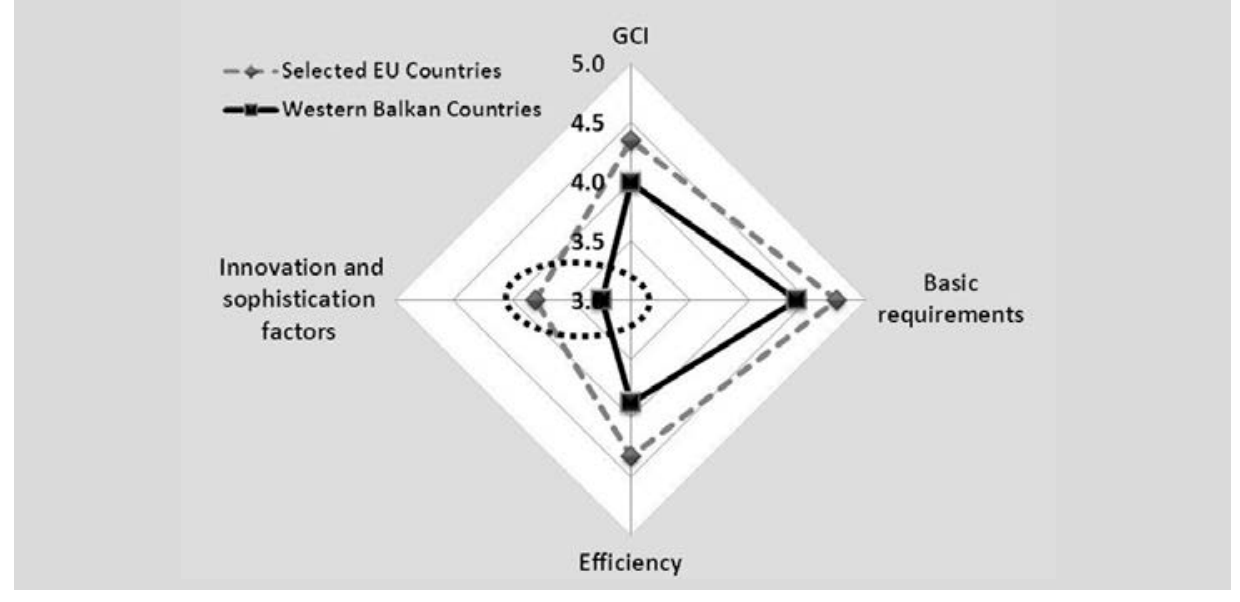

Calculated according to: WEF, 2012.

The biggest gap has been noted in respect of the sub-indices innovativeness and business sophistication, which points to the fact that the Western Balkan countries do not base their productivity and competitiveness on high business sophistication (XI pillar) and innovativeness (XII pillar) that make up this subindex. It is obvious that the entire region in its development predominantly relies on relatively cheap labor. Cheap labor, low income taxes and their closeness to the EU market are the main advantages of the Western Balkan countries, while technological readiness, lifelong learning, and fostering innovativeness of companies are still not recognized as the dimensions on which the future competitiveness of these countries should be based on (Crnković-Stumpf et.al, 2011). 
Cvetanović S. et al.: Knowledge Economy Readiness, Innovativeness and...

\section{Interdependence of KEI, GII, and GCI of the Western Balkan countries and the selected EU countries}

The analysis of interdependence among the observed composite indices has been carried out by establishing a hypothetical model of interdependence among the observed indices. The model is based on the previous research of the impact of the body of knowledge on the improvement of innovativeness (Lester, 2005; Cooke, 2001, 2004, Chen \& Huang, 2009; Frenz \& LettoGillies, 2009), the perception of improvement of innovativeness on the growth of competitiveness (Betz, 2003; Coenen \& Díaz López, 2010; Carneiro, 2000), as well as on the research of the dynamics of interaction of the national intellectual capital, the economy's competitiveness and economic performance of countries (Ståhle and Ståhle 2006).

Starting from the three above-mentioned reference methodological frameworks, the variables $\mathrm{KEI}$, GII, IER and $\mathrm{GCl}$ have been singled out and included in the model. The overlapping of the range of variables that exist in particular between the metrics of the $\mathrm{GIl}$ the and $\mathrm{GCl}$ is neglected because the calculation used only end aggregate values which represent the highest level of abstraction. In future more detailed studies on this subject, relying on the multiple correlation analysis at lower levels of abstraction, the previous testing of multicollinearity of the observed independent variables must be conducted.

Fig. 7 shows the assumed model of interdependence among the observed variables.

Figure 7. Illustration of the hypothetical model of interdependence among KEI, GII, IER and $\mathrm{GCl}$

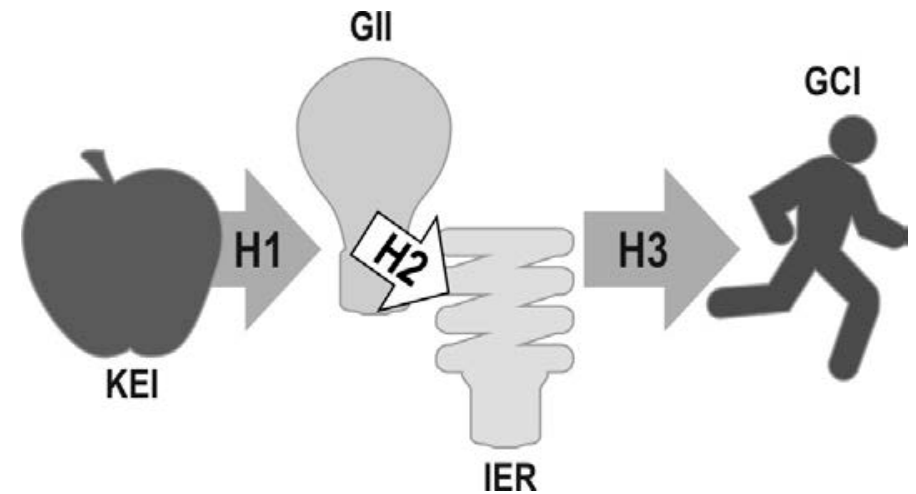


Cvetanović S. et al.: Knowledge Economy Readiness, Innovativeness and...

Based on the foregoing analyses and the established initial model of interdependence among KEI, GII, IER (ratio of innovation input index (III) and innovation output index (IOI) in the $\mathrm{GII}$ ) and $\mathrm{GCl}$, the hypotheses are established, that should indicate the significance of the interaction among the variables:

$\mathrm{H} 1$ : Pronounced knowledge economy readiness (represented by the value of KEI) has a positive impact on improving the innovativeness of the economy, quantified by the GII.

H2: Higher achieved level of innovativeness of the economy (GII) implies greater efficiency of the innovation system, represented by the indicator IER.

H3: Higher GII has a positive impact on increasing the country's competitiveness, quantified by $\mathrm{GCl}$.

The hypothesis $\mathrm{H} 1$ is based on the assumption that increasing knowledge economy readiness at the national level improves innovativeness of companies and countries. Additional support to the hypothesis $\mathrm{H} 1$ lies in the much broader time frame for monitoring the national economies by KEI value in relation to the annual trend of the GII index, which in itself gives time shift in observing the impact of hypothetically independent variable KEI on the dependent variable GII.

The hypothesis $\mathrm{H} 2$ can be called an inter-innovative hypothesis, or even pseudorecursive hypothesis, because both variables belong in the domain of the GII. The base assumption is that the increase in the value of the parameter IER is the result of improved performance of the national innovation system. We believe that the impact of the variable IER on improving a country's competitiveness is very intriguing for deeper study.

$\mathrm{H} 3$ is a universal hypothesis, dealing with the connection between innovativeness of the economy and the competitiveness of a country. At the national level, it can be studied through the influence of the independent variable GII (as the aggregate innovative performance) on the dependent variable $\mathrm{GCl}$, as the aggregate indicator of the level of competitiveness of the economy. This hypothesis examines the extent to which a country's competitiveness is based on its innovative performance, as a global paradigm of future economic progress.

The process of statistical analysis has been carried out in three steps: in the first step, the summary statistical data for both groups of countries has been calculated and presented in the form of box-plot diagram. The goal has been to identify the presence of extreme values, as well as the degree of homogeneity, variation, and asymmetry of the obtained data. Given the relative homogeneity, symmetry, small degree of variation, and lack of 
Cvetanović S. et al.: Knowledge Economy Readiness, Innovativeness and...

extremes (except for Croatia in the case of variable KEI and Austria in the case of $\mathrm{GCl}$ ), the investigation continued. The second stage was the investigation of the degree of interdependence among the observed variables in the model, based on the determination of the Pearson correlation coefficient. In the third step, the pairs of variables with statistically significant correlation coefficients were shown by single linear regression analysis.

Based on the data collected from the reference database, in the first step the summary statistics for both groups of countries was given (Table 1). Data was partially normalized (GII and IER were normalized) so that all variables ranged from $0-10$, except for the $\mathrm{GCl}$ variable, whose range remained in its original form from 1-7.

Table 1. Summary statistics of variables correlation of the Western Balkan countries and the selected EU countries

\begin{tabular}{|c|c|c|c|c|c|c|c|c|c|c|}
\hline \multirow{2}{*}{ Variable } & \multicolumn{2}{|c|}{ Min } & \multicolumn{2}{|c|}{ Max } & \multicolumn{2}{|c|}{ Mean } & \multicolumn{2}{|c|}{$\begin{array}{c}\text { Std. } \\
\text { deviation }\end{array}$} & \multicolumn{2}{|c|}{$\begin{array}{l}\text { Coefficient of } \\
\text { variations }\end{array}$} \\
\hline & WB & EU & WB & EU & WB & EU & WB & EU & WB & EU \\
\hline KEI & 4.53 & 6.80 & 7.29 & 8.61 & 5.72 & 7.63 & 0.931 & 0.723 & 0.163 & 0.095 \\
\hline GII & 30.85 & 37.71 & 41.95 & 51.87 & 37.67 & 44.25 & 3.948 & 5.317 & 0.105 & 0.120 \\
\hline IER & 0.58 & 0.65 & 0.82 & 0.91 & 0.73 & 0.80 & 0.089 & 0.106 & 0.123 & 0.132 \\
\hline $\mathrm{GCl}$ & 3.87 & 3.86 & 4.14 & 5.22 & 3.99 & 4.34 & 0.102 & 0.466 & 0.026 & 0.107 \\
\hline
\end{tabular}

Calculated according to: a) database on: http://info.worldbank.org/etools/kam2; b) WEF, 2012; c) Dutta \& Lanvin 2013.

Fig. 8 shows the box plot diagrams for the four observed variables for the two observed groups of European countries. In descriptive statistics, box plot or boxplot (also known as a box-and-whisker diagram or plot) is a convenient way of graphical representation of numerical data through a summary of five parameters: the minimum value of the numerical data set, the bottom quartile (Q1), median (Q2), upper quartile (Q3), and the maximum value of numerical data sets. Box plot indicates the presence of extreme values, and also the differences between populations, without making any assumptions that are based on the analysis of statistical distribution (non-parametric mode). The distance between the different parts of this display indicates the degree of data dispersion (scatter) and the asymmetry, as well as the recognition of gross errors in terms of outliers. 
Cvetanović S. et al.: Knowledge Economy Readiness, Innovativeness and...

Figure 8. Box plot (6 Western Balkan and 6 EU countries)

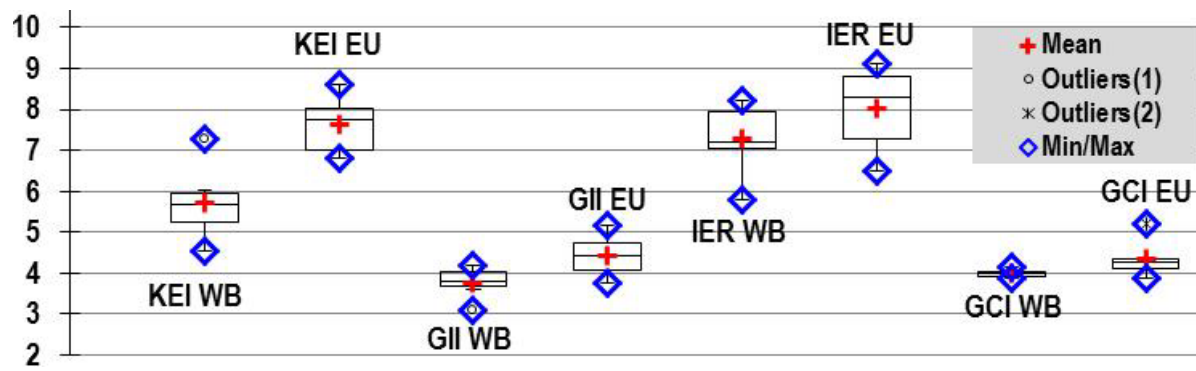

Calculated according to: a) database on: http://info.worldbank.org/etools/kam2; b) WEF, 2012; c) Dutta \& Lanvin 2013.

Based on Fig. 8, it is possible to formulate the following conclusions:

- There is an approximately similar distribution of box plot diagrams for individual composite indices in the Western Balkan countries and the observed EU countries;

- Both in the case of the Western Balkan countries and the selected EU countries, the largest median of individually observed indices was noted within the IER;

- Within both groups of observed countries, the highest homogeneity of countries was noted within the framework of the $\mathrm{GCl}$;

- Although similar trends were observed in the distribution of four observed indices, one should not ignore the fact that the average values for each index for the group of EU countries are at a higher level than the average values of these indices for the Western Balkan countries;

- There are some atypical values in terms of the extremely positive deviation of Croatia within the group of Western Balkan countries in relation to KEI and Austria within the EU countries in relation to the variable $\mathrm{GCl}$.

The average values and the values of the quartiles and the median of the observed innovative performance for both groups of countries that are included in the analysis show that the data is comparable and relatively homogeneous.

The remaining part of the work shows the correlation matrix among the observed variables for the Western Balkan countries (Fig. 9) and the selected EU countries (Fig. 11). Based on the matrix, the pairs of variables with significant coefficients were singled out (Values with a significance level alpha $=0.05$; in our case $\mathrm{R}>=0.811$ ), and presented in detail in the form of regression diagrams (Fig. 10 and Fig. 12). 
Cvetanović S. et al.: Knowledge Economy Readiness, Innovativeness and...

Figure 9. Correlation matrix according to $R$ for GII, IER, GCl and KEI for the Western Balkan countries

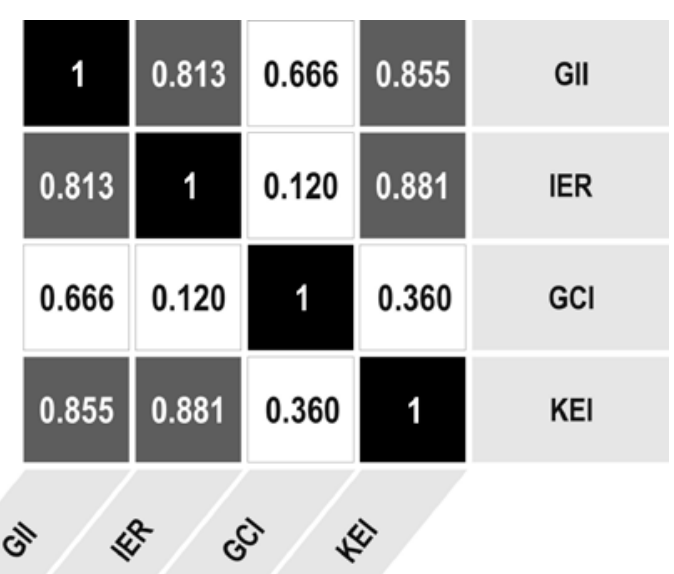

Calculated according to: a) database on: http://info.worldbank.org/etools/kam2; b) WEF, 2012; c) Dutta \& Lanvin 2013.

Note: Values in grey squares are different from 0 with a significance level alpha $=0.05$

Figure 10. The scatter diagram and the regression line for a) $G I I=f(K E I)$ and b) $I E R=f(G I I)$ in the Western Balkan countries
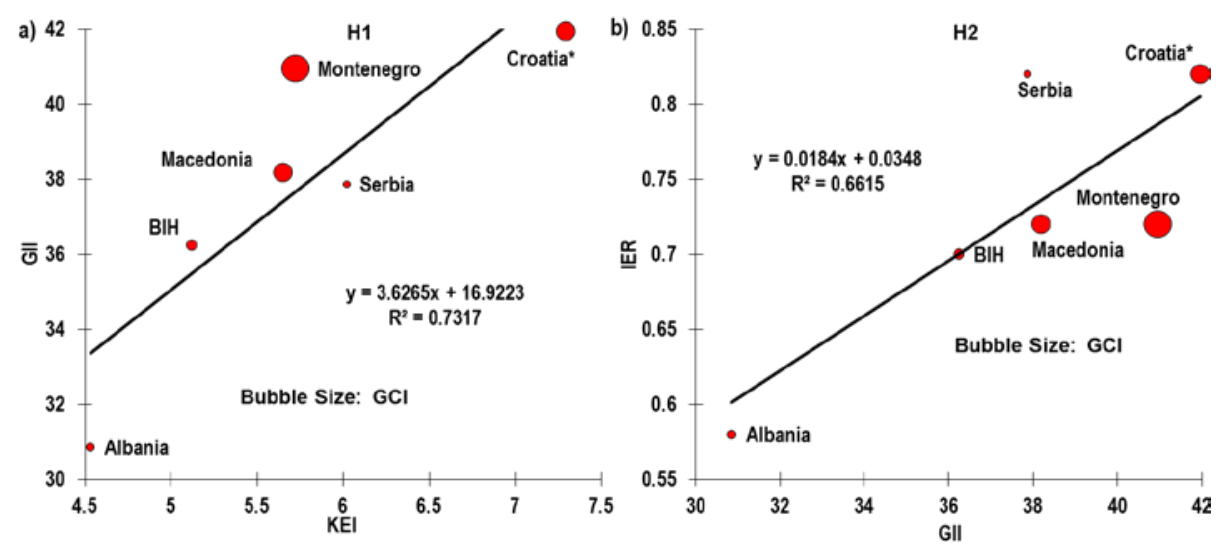

Annotation: Size of the bubble shows the relative ratio of the value of $\mathrm{GCl}$ Calculated according to: a) database on: http://info.worldbank.org/etools/kam2; b) WEF, 2012; c) Dutta \& Lanvin 2013. 
Cvetanović S. et al.: Knowledge Economy Readiness, Innovativeness and...

Based on the analysis of the presented relations, one can conclude that in the case of the group of Western Balkan countries, the hypotheses $\mathrm{H} 1$ and $\mathrm{H} 2$ are statistically confirmed, while for the hypothesis $\mathrm{H} 3$, there is no statistically relevant evidence. Therefore, the Western Balkan countries with higher values of KEI have higher levels of GII, and thus the higher level of IER. The lack of statistical evidence for the hypothesis $\mathrm{H} 3$ points to the fact that competitiveness of the Western Balkan countries is still not based on the development of innovation potential (Albania, Serbia, Bosnia and Herzegovina, Macedonia, and Montenegro are in the developmental stage, where their competitiveness is based on the efficient use of factors of production, while only Croatia is in a transitional phase from the efficiencydriven to innovation-driven economy).

Fig. 11 shows the correlation matrix among the observed variables for the group of selected EU countries.

Figure 11. Correlation matrix according to $R$ for the observed parameters GII, $I E R, G C l$ and KEI for a group of selected EU countries

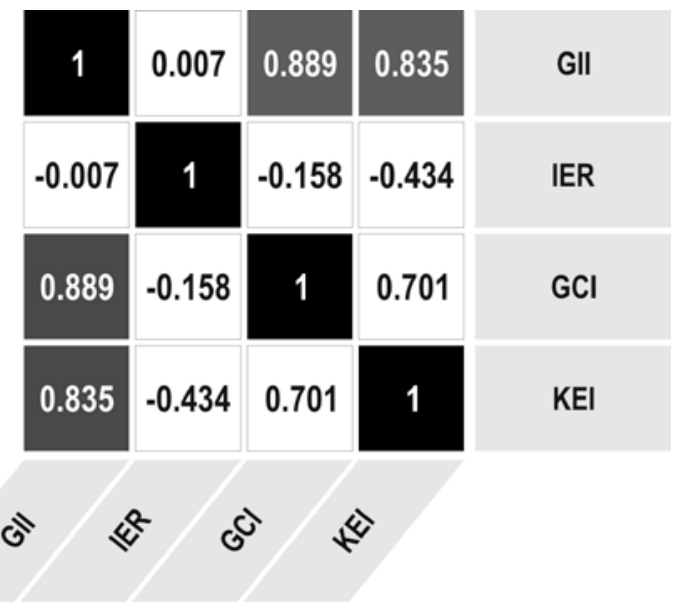

Note: Values in grey squares are different from 0 with a significance level alpha $=0.05$. Calculated according to: a) database on: http://info.worldbank.org/etools/kam2; b) WEF, 2012; c) Dutta \& Lanvin 2013.

It is noted that for a group of selected EU countries, a statistically significant value of Pearson's correlation coefficient is confirmed by data pairs KEI-GII and $\mathrm{GII-GCl}(\mathrm{R}=0.835$ and $\mathrm{R}=0.889$, respectively), which is more than the limit value equal to 0.811 for the level of significance of $5 \%$.

Fig. 12 shows the dependence of KEI on GII and of $\mathrm{GCl}$ on GIl for six EU countries, obtained by the single linear regression $(y=a+b x)$. The analysis 
Cvetanović S. et al.: Knowledge Economy Readiness, Innovativeness and...

of the presented relations points to the conclusion that the hypotheses $\mathrm{H} 1$ and $\mathrm{H} 3$ are confirmed with significant statistical significance. For the hypothesis $\mathrm{H} 2$, there are no statistically relevant indications.

Figure 12. Scatter diagram and regression line for a) $G I I=f(K E I)$ and b) $G C l=$ $f(G I I)$ for the selected EU countries
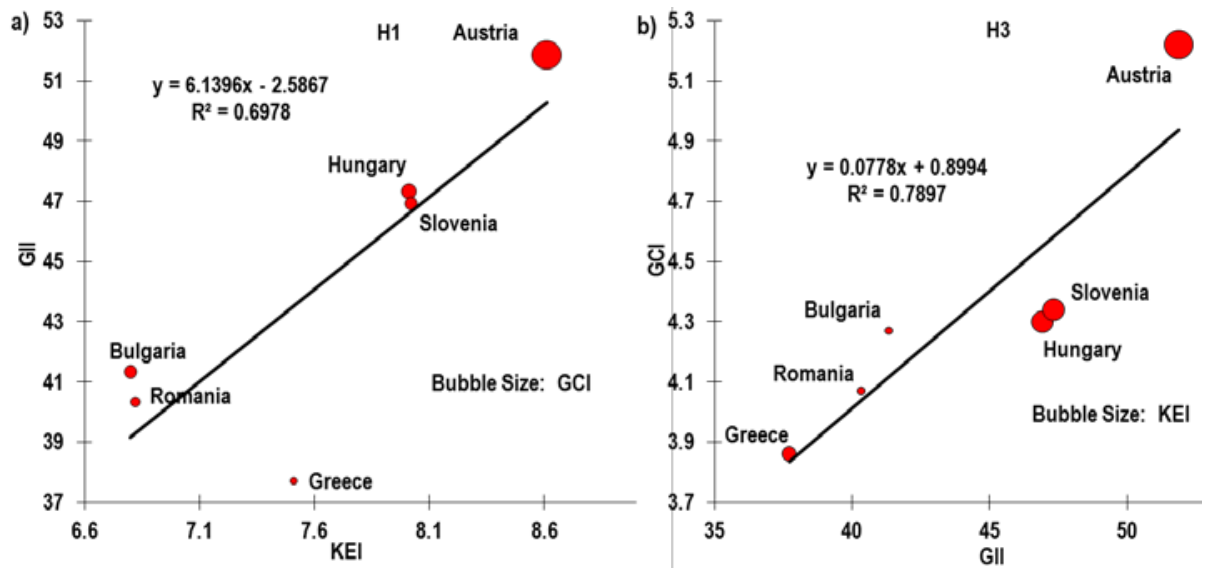

Annotation: size of the bubble shows: a) the relative ratio of the value of $\mathrm{GCl}$; b) the relative ratio of the value of $K E I$

Calculated according to: a) database on: http://info.worldbank.org/etools/kam2; b) WEF, 2012; c) Dutta \& Lanvin 2013.

The detected significant correlation KEI-GII (Fig. 12 on the left), as the confirmation of the hypothesis $\mathrm{H} 1$, suggests that the achieved level of innovativeness of the selected EU countries is based on the achieved level of knowledge economy. Countries with higher KEI values have higher levels of GII. Furthermore, according to the hypothesis $\mathrm{H} 3$, countries with higher values of $\mathrm{GIl}$ have a higher $\mathrm{GCl}$. The detected correlation $\mathrm{GII-GCl}$ points to the fact that a group of EU neighbors base their competitiveness significantly on the available innovative potential (Austria, Greece, and Slovenia are innovationdriven economies, Hungary is in the transition process towards them, while Romania and Bulgaria still base their competitiveness on efficient use of production factors).

The hypothesis $\mathrm{H} 2$ cannot be confirmed on the basis of the presented data, indicating the possibility that the selected EU countries invest more resources in developing their own innovation systems, and that the efficiency of their national innovation systems, quantified by the indicator IER, is left in the background. This may be explained by the multiple effects of growth of innovativeness of the economy on the improvement of a country's 
Cvetanović S. et al.: Knowledge Economy Readiness, Innovativeness and...

competitiveness, which ultimately erases losses due to insufficient efficiency of innovation systems.

It is interesting that the hypothesis $\mathrm{H} 2$ is confirmed in the case of the Western Balkan countries, according to which growth of innovativeness of the economy is accompanied by increased efficiency of innovation systems, measured by IER. The explanation for this may be the high degree of sensitivity of national innovation systems that are in the early stages of development. However, we believe that this is largely an echo of high innovation outputs, inherited from the pre-transition period, since, with the exception of Albania, these are countries with historically respectable educational traditions. Despite indicated confirmation of the hypothesis $\mathrm{H} 2$, the multiple effect of GII on the growth of $\mathrm{GCl}$ in the Western Balkan countries is lacking.

The following Fig. 13 provides an illustration of results of proving the established hypotheses in both groups of observed countries.

Figure 13. Illustration of the confirmation of the hypothetical model of interdependence among the indicators KEI, GII, IER and GCI for the Western Balkan countries and the selected EU countries.

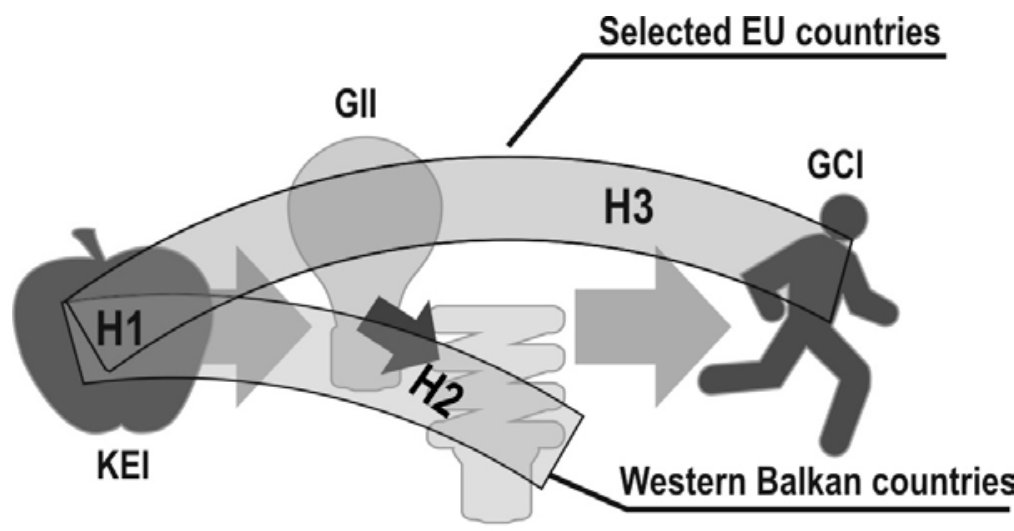

IER

Finally, it should be noted that the causality of the above established and examined hypotheses is very questionable. Therefore, the future direction of research (which is beyond the scope of this paper) implies further proving of the established hypotheses. Further analysis would, among other things, require the involvement of the time dimension and the investigation of the socalled lag effect. This would require processing of the time shifted data (data used for the calculation of independent variables should be taken from the 
Cvetanović S. et al.: Knowledge Economy Readiness, Innovativeness and...

period preceding the time period from which the data for dependent variables are taken). Therefore, it would be necessary to create separate data sets for each hypothesis where the following condition is met:

$$
x_{t}=a+b y_{t+n}
$$

where:

$\mathrm{a}, \mathrm{b}$ - constants of the linear model;

$\mathrm{x}$ - independent (exogenous) variable (KEI in $\mathrm{H} 1, \mathrm{GIl}$ in $\mathrm{H} 2$ and $\mathrm{H} 3$ );

$y$ - dependent (endogenous) variable (GII in $\mathrm{H} 1$, IER in $\mathrm{H} 2$, and $\mathrm{GCl}$ in $\mathrm{H} 3$ );

$\mathrm{t}$ - time;

$\mathrm{n}$ - the time interval between measurements of independent $\mathrm{X}$ and dependent Y variable.

By varying the interval $\mathrm{n}$ for each individual hypothesis, more exact functional model that describes the causality of the observed variables would be obtained.

\section{Conclusion}

The conducted research provides a solid basis for answering the main question posed in the paper - how much are the Western Balkan countries ready for the knowledge economy, innovativeness and competitiveness, compared to the EU countries that surround this region. In short, the Western Balkan countries as a group are significantly lagging behind the selected EU countries, in respect of all three analyzed indices. When Croatia, which joined the EU on 1 July 2013, is omitted from the group of Western Balkan countries, this gap is even more pronounced. Therefore, improving the readiness of countries for the knowledge economy must be the focus of all actions that aim to increase innovativeness and improve competitiveness. It is necessary to accelerate the construction of institutions, infrastructure, and promote political stability in the Western Balkan region, as these are critical factors of innovativeness and competitiveness.

Knowledge and innovativeness are closely linked (KEI-GII). In fact, the correlation between the accumulation of knowledge, measured by $\mathrm{KEI}$, and the level of innovativeness of the economy, quantified by GII values, for both groups of countries indicates a statistically significant value of Pearson's coefficient. Countries with higher KEI values have higher levels of innovativeness and vice versa. This positive correlation does not establish a causal relationship between KEl and innovativeness. It is likely that countries 
Cvetanović S. et al.: Knowledge Economy Readiness, Innovativeness and...

with high income can use their wealth and invest more in the creation and distribution of knowledge. Correlation itself does not definitely prove that the strengthening of certain forms of knowledge in the Western Balkans will in the foreseeable period certainly result in higher values of GII. Further analysis would involve deepening the analysis and including the time component in terms of testing the so-called lag effect.

The assumption on the basis of which the increase in the level of innovativeness is accompanied by increased efficiency of national innovation systems has proved to be true for the group of Western Balkan countries. The explanation for this may be the high sensitivity of innovation systems that are in the early stages of development, but also an echo of the pre-transition period. On the other hand, when EU countries are taken into consideration, there is no evidence of the positive impact of the level of GII on IER.

Significant interdependence GII-GCl in six EU neighbors suggests that the competitiveness of these countries relies heavily on the use of innovation potential that they possess. In contrast, the lack of significant correlation GII$\mathrm{GCl}$ in six countries of the Western Balkans indicates that these countries do not rely on their low innovative potential in their struggle to improve competitiveness.

Low innovativeness of the Western Balkan countries, in addition to the existing political, economic, legal, and security challenges, is the slowing factor of their EU accession.

\section{References}

Acs, Z. J., de Groot, H. L., \& Nijkamp, P. (Eds.). (2013). The emergence of the knowledge economy: A regional perspective. Springer Science \& Business Media.

Atkinson, R. D., \& Ezell, S. J. (2012). Innovation economics: the race for global advantage. Yale University Press.

Barro, R. J., \& Sala-i-Martin, X. (2003). Economic growth. MIT Press Books, 1.

Betz, F. (2003). Managing technological innovation: competitive advantage from change. John Wiley \& Sons.

Carneiro, A. (2000). How does knowledge management influence innovation and competitiveness? Journal of knowledge management, 4(2), 87-98.

Chen, D. H., \& Dahlman, C. J. (2005). The knowledge economy, the KAM methodology and World Bank operations. World Bank Institute Working Paper, (37256).

Chen, C. \& Huang, J. (2009). Strategic human resource practices and innovation performance-The mediating role of knowledge management capacity. Journal of Business Research, 62(1), 104-114.

Coenen, L. \& Díaz López, F. (2010). Comparing systems approaches to innovation and technological change for sustainable and competitive economies: an 
Cvetanović S. et al.: Knowledge Economy Readiness, Innovativeness and...

explorative study into conceptual commonalities, differences and complementarities. Journal of Cleaner Production, 18(12), 1149-1160.

Cooke, P. (2001). Regional innovation systems, clusters, and the knowledge economy. Industrial and corporate change, 10(4), 945-974.

Cooke, P. (2004). The role of research in regional innovation systems: new models meeting knowledge economy demands. International Journal of Technology Management, 28(3), 507-533.

Crnković-Stumpf, B., Katunar, J., \& Cerović, L. (2011, April). Competitiveness of small and medium enterprises in Western Balkan Countries: What can they learn from EU area?. In 8th International Conference" Economic Integrations, Competition and Cooperation" Session 11: Western Balkans; trade, cooperation and EU integration perspective.

Cvetanović, S., \& Nedić, V. (2013). An analysis of innovation performance of the Western Balkan countries and the EU selective economies group.Medjunarodni problemi, 65(1), 68-84.

Cvetanović, S. Despotović, D. Živković, Lj. Nedić, V. (2014). Environmental Dimension of Sustainable Competitiveness of Serbia and Selected European Countries. Bulgarian Journal of Agricultural Science, No 4.

Delgado, M., Ketels, C., Porter, M. E., \& Stern, S. (2012). The determinants of national competitiveness (No. w18249). National Bureau of Economic Research.

Despotović, D., Cvetanović, S. \& Nedić, V. (2014). Innovativeness and Competitiveness of the Western Balkan Countries and Selected EU Member States. Industrija, 42(1).

Dutta, S. (2012). The global innovation index 2012. Stronger Innovation Linkages for Global.

Dutta, S., \& Lanvin, B. (Eds.). (2013). The Global Innovation Index 2013: The Local Dynamics of Innovation.

Drucker, P. (1969). The Age of Discontinuity. New York: Harper \& Row

Drucker, P. F., \& Drucker, P. F. (1993). Post-capitalist society. Routledge.

Frenz, M., \& Letto-Gillies, G. (2009). The impact on innovation performance of different sources of knowledge: Evidence from the UK Community Innovation Survey. Research Policy, 38(7), 1125-1135.

Freeman, C. (1987). Technology policy and economic performance: lessons from Japan.

Garelli, S. (2012). The fundamentals and history of competitiveness. IMD World competitiveness yearbook 2012, 488, 503.

Huggins, R. A., \& Izushi, H. (2007). Competing for knowledge: creating, connecting and growing. Routledge.

Kitson, M., Martin, R., \& Tyler, P. (2004). Regional competitiveness: an elusive yet key concept?. Regional studies, 38(9), 991-999.

Lall, S. (2001). Competitiveness indices and developing countries: an economic evaluation of the global competitiveness report. World development,29(9), 15011525.

Lester, R. (2005). Universities, innovation, and the competitiveness of local economies. A summary Report from the Local Innovation Systems Project: Phase I. Massachusetts Institute of Technology, Industrial Performance Center, Working Paper Series.

Lundvall, B. A. (1992). National innovation system: towards a theory of innovation and interactive learning. Pinter, London. 
Cvetanović S. et al.: Knowledge Economy Readiness, Innovativeness and...

Machlup, F. (2014). Knowledge: Its Creation, Distribution and Economic Significance, Volume III: The Economics of Information and Human Capital(Vol. 3). Princeton University Press.

Nedić, V. Cvetanović,S. Despotović, D, (2013). Divergence of th innovativeness and competitiveness of European Countries in the Period 2006-2012. Metalurgia International No. 9, $187-183$

Nelson, R. (1993). National Innovation System: A Comprehensive Analysis. New York: Oxford University Press

Önsel, Ş., Ülengin, F., Ulusoy, G., Aktaş, E., Kabak, Ö., \& Topcu, Y. I. (2008). A new perspective on the competitiveness of nations. Socio-Economic Planning Sciences, 42(4), 221-246.

Porter, M. E. (1990). The Competitive Advantage of Notions. Harvard business review.

Romer, P. (1990). Endogenous Technological Change. Journal of Political Economy, 98(5): 71-102

Porter, M., \& Rivkin, J. W. (2012). The looming challenge to US competitiveness. Harvard Business Review, 90(3), 54-61.

Ståhle, P., \& Ståhle, S. (2006). Intellectual capital and national competitiveness: conceptual and methodological challenges. Capital immatériel, connessaince et performance, 415-29.

Solow, R. M. (1956). A contribution to the theory of economic growth. The quarterly journal of economics, 65-94.

Huggins, R., \& Izushi, H. (2002). The digital divide and ICT learning in rural communities: examples of good practice service delivery. Local Economy,17(2), 111-122.

Staskevičiūtè, G., \& Tamošiūnienè, R. (2010). The Evaluation of the National Competitiveness: Analysis of Existing Means. 6th International Scientific Confernece „Business and Management". Vilnius, Lithuania

Ülengin, F., Kabak, Ö., Önsel, S., Aktas, E., \& Parker, B. R. (2011). The competitiveness of nations and implications for human development. SocioEconomic planning sciences, 45(1), 16-27.

Zubović, J. (2010). Razvoj privrede zasnovan na ulaganjima u ljudske resurse i stranim investicijama. Institut ekonomskih nauka, Belgrade, 39-57.

WEF. (2012). The Global Competitiveness Report 2012-2013. World Economic Forum, Geneva.

World Bank. (2013). Knowledge Assessment Methodology (KAM). Available at: http://info.worldbank.org/etools/kam2/KAM_page5.asp 